\title{
WPLYW ZMIAN STOPY PROCENTOWEJ EBC NA INFLACJE I AKTYWNOŚĆ GOSPODARCZĄ STREFY EURO - WERYFIKACJA ZA POMOCĄ MODELU AUTOREGRESJI WEKTOROWEJ (VAR)
}

\section{Wstęp}

W stabilnych warunkach gospodarczych polityka Europejskiego Banku Centralnego (EBC), tak jak innych banków centralnych, wpływa na poziom stóp procentowych na rynku pieniężnym. Sytuacja na tym rynku przekłada się na inne stopy procentowe, m.in. stopy oprocentowania kredytów oraz depozytów. Następnie różnymi kanałami polityka pieniężna oddziałuje na ceny oraz na całą gospodarkę. Ten skomplikowany proces jest znany jako mechanizm transmisji polityki pieniężnej (transmission mechanism of monetary policy).

W następstwie zaburzeń na światowych rynkach finansowych, wywołanych upadkiem banku Lehman Brothers, mechanizm transmisji monetarnej EBC przestał sprawnie funkcjonować. Prawidłowy proces przenoszenia impulsów polityki pieniężnej do gospodarki realnej został zakłócony, przede wszystkim, przez kryzys zaufania na rynku międzybankowym oraz zwiększoną awersję banków komercyjnych do ponoszenia ryzyka.

Celem niniejszego artykułu jest próba porównania wpływu zmian oficjalnej stopy procentowej EBC na inflację i aktywność gospodarczą strefy euro w okresie przed globalnym kryzysem finansowym i z uwzględnieniem czasu kryzysu. $\mathrm{W}$ badaniu zastosowano modele autoregresji wektorowej (VAR) oraz narzędzia związane z tymi modelami. Przeprowadzona została analiza struktury powiązań pomiędzy zmiennymi za pomocą testowania przyczynowości w sensie Grangera, funkcji odpowiedzi na impuls i dekompozycji wariancji.

\section{Mechanizm transmisji impulsów polityki pieniężnej EBC}

Teoretyczny kształt mechanizmu transmisji impulsów polityki pieniężnej jest prezentowany w literaturze przedmiotu na różne sposoby. P.N. Ireland określa go, jako proces w wyniku którego polityka monetarna, poprzez zmiany wielkości podaży pieniądza lub nominalnych krótkoterminowych stóp procen-

*Doktorantka, Katedra Międzynarodowych Stosunków Gospodarczych, Wydział Ekonomiczno-Socjologiczny UŁ. 
towych, wpływa na zmienne realne, takie jak zagregowana produkcja czy wysokość zatrudnienia ${ }^{1}$. I. Pszczółka podkreśla, że bank centralny poprzez mechanizm transmisji monetarnej wywiera wpływ na relatywne ceny oraz realny wzrost $\mathrm{PKB}^{2}$. Z kolei J. Rosiek definiuje mechanizm transmisji monetarnej, ,jako działania instytucji i podmiotów gospodarczych stanowiące drogę, poprzez którą polityka banku centralnego oddziałuje na decyzje cenowe i produkcyjne aktorów życia ekonomicznego ${ }^{3 "}$.

Proces transmisji jest bardzo skomplikowany, podlega zmianom w czasie i może różnic się między poszczególnymi gospodarkami. Zawiera wiele zależności pomiędzy podmiotami gospodarczymi oraz charakteryzuje się długimi i zmiennymi w czasie opóźnieniami.

Na rysunku 1 zostały przedstawiony mechanizm transmisji impulsów polityki pieniężnej, za pomocą których EBC realizuje swój cel finalny, jakim jest osiągniecie i utrzymanie stabilnego poziomu cen w strefie euro. Analizując ten układ zależności można zauważyć, że zmiany stóp procentowych EBC w pierwszej kolejności wywołują wahania rynkowych stóp procentowych oraz wpływają na oczekiwania uczestników życia gospodarczego. Następnie powodują zmiany produkcji i w ostateczności przyczyniają się do zmiany ogólnego poziomu cen.

Powyższy schemat pokazuje, że wpływ polityki pieniężnej na inflację oraz aktywność gospodarczą następuje za pośrednictwem kilku kanałów, poprzez które decyzje banku centralnego oddziałują na sferę realną i pieniężną. W literaturze przedmiotu do standardowych kanałów transmisji zalicza się ${ }^{4}$ :

1) kanał stopy procentowej (interestrate channel),

2) kanał kredytowy (credit channel),

3) kanał majątkowy (asset price channel),

4) kanał kursu walutowego (exchange rate channel).

Ze względu na ich wzajemne powiązania, często trudno jest precyzyjnie rozróżnić te kanały. $\mathrm{Z}$ tego powodu $\mathrm{w}$ niniejszym artykule ograniczono się do pokazania i skomentowania dwóch podstawowych własności mechanizmu transmisji, jakimi są reakcja produkcji i inflacji na impuls stopy procentowej.

${ }^{1}$ P.N. Ireland, The monetary transmission mechanism, Federal Reserve Bank of Boston, Working Papers 2005, no. 60-1, s. 1.

${ }^{2}$ I. Pszczółka, Mechanizmy transmisyjne zmian podaży pieniądza i nominalnych stóp procentowych, [w:] J.L. Bednarczyk (red.), Teoria i polityka stóp procentowych we wspótczesnej gospodarce, Wyd. Politechniki Radomskiej, Radom 2007, s. 155.

${ }^{3}$ J. Rosiek, Polityka monetarna $w$ dobie kryzysu gospodarczego - wybrane aspekty oddziatywania, [w:] Z. Dach (red.), Polityka makroekonomiczna $w$ warunkach kryzysu i jej wplyw na gospodarkę. Teoria i praktyka, Wolters Kluwer, Warszawa 2011, s. 123.

${ }^{4}$ I. Pszczółka, Mechanizmy transmisyjne..., s. 155. 


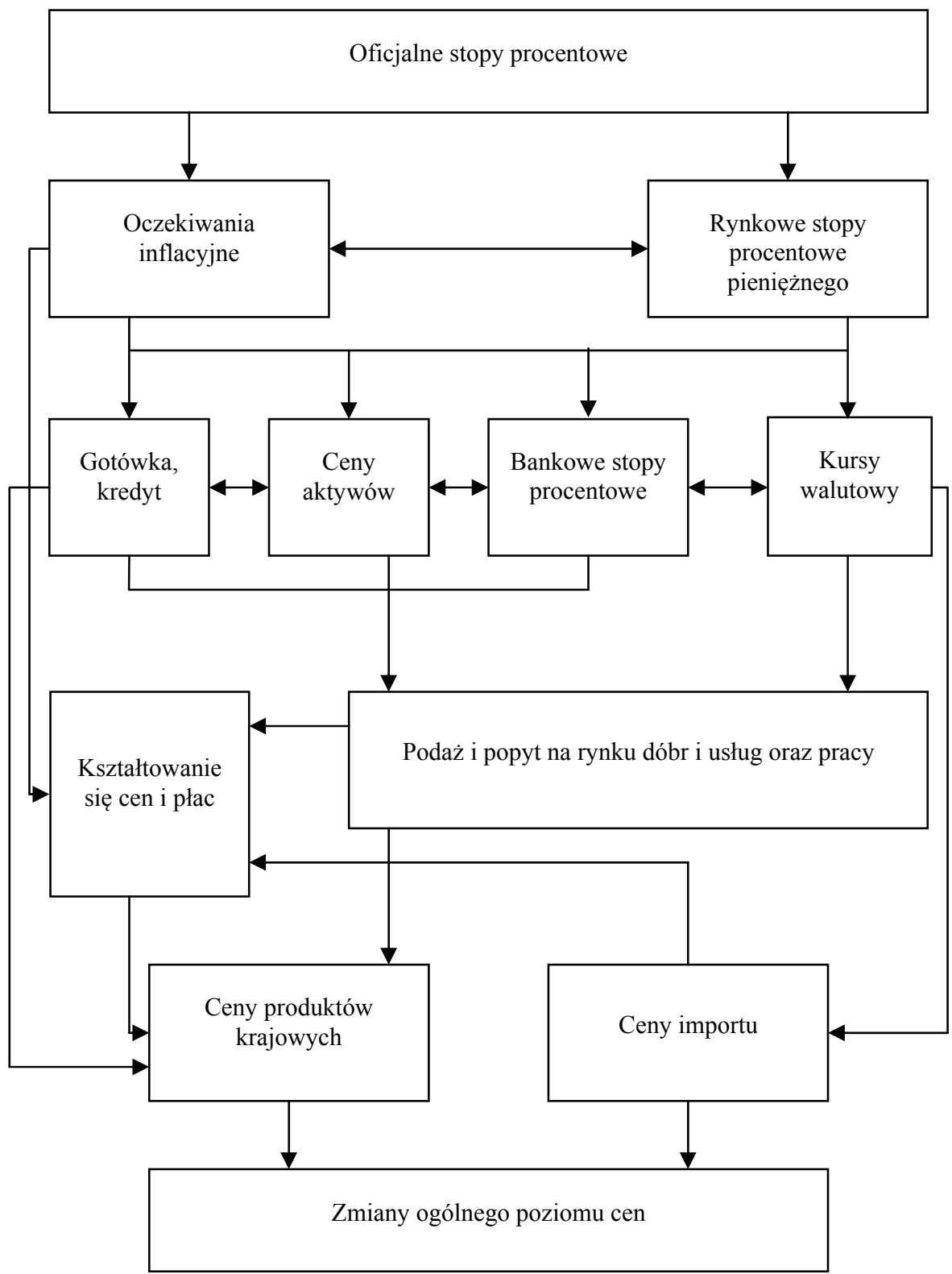

Rysunek 1. Mechanizm transmisji impulsów polityki pieniężnej Europejskiego Banku Centralnego

Źródło: opracowanie własne na podstawie European Central Bank, The Monetary Policy of the $E C B$, Frankturt am Mein2011, s. 59.

Z punktu widzenia dalszych rozważań, szczególną uwagę należy zwrócić na kanał stopy procentowej, który przed globalnym kryzysem finansowym uważa- 
ny był za główny mechanizm transmisji impulsów polityki pieniężnej ECB. Poprzez tą drogę bank centralny Eurosystemu bezpośrednio wpływa na krótkoterminowe stopy procentowe na międzybankowym rynku pieniężnym. Następnie za pośrednictwem instytucji finansowych oddziałuje na dynamikę życia gospodarczego ${ }^{5}$. F.S. Mishkin wskazał, że proces ten wynika $\mathrm{z}$ keynesowskiego modelu IS-LM ${ }^{6}$.

$$
M \uparrow \Rightarrow i \downarrow \Rightarrow i_{r} \downarrow \Rightarrow I \uparrow \Rightarrow Y \uparrow
$$

gdzie:

$M$ - podaż pieniądza,

$i$ - nominalna rynkowa stopa procentowa,

$i_{p}$ - realna stopa procentowa,

$\boldsymbol{I}$ - wydatki inwestycyjne,

$Y$ - zagregowany produkt (PKB).

Analizując powyższy łańcuch przyczyno-skutkowy można odnotować, że wyniku w ekspansywnej polityki pieniężnej dochodzi do spadku rynkowych stóp procentowych. Zmniejszeniu ulega także poziom realnych stóp procentowych, z powodu występującej w gospodarce sztywności cen ${ }^{7}$. Spadek realnych stóp procentowych obniża koszt pozyskania kapitału, zwiększając skłonność przedsiębiorstw do inwestycji. Niskie stopy procentowa powodują również wzrost zakupów nieruchomości oraz dóbr trwałego użytku przez gospodarstwa domowe. W efekcie sytuacja ta prowadzi do wzrostu zagregowanego popytu oraz globalnej produkcji.

$\mathrm{Z}$ teoretycznego punktu widzenia wpływ realnych stóp procentowych na decyzje inwestycyjne i konsumpcyjne, umożliwia transmisję impulsów polityki pieniężnej do gospodarki realnej nawet $\mathrm{w}$ okresach deflacji, gdy nominalne stopy procentowe spadają do poziomu bliskiego lub równego zera. W takim przypadku, przedstawiony powyżej schemat (1) można zapisać w odmienny sposób, jako ${ }^{8}$ :

$$
M \uparrow \Rightarrow P^{*} \uparrow \Rightarrow \pi^{*} \uparrow \Rightarrow i_{r} \downarrow \Rightarrow I \uparrow \Rightarrow Y \uparrow
$$

gdzie:

$p=1-$ wzrost oczekiwanego poziomu cen (expected pricelevel),

$\pi^{*}$-oczekiwania inflacyjne (expected inflation).

\footnotetext{
${ }^{5}$ W. Przybylska-Kapuścińska, Mechanizm i kanaty transmisji polityki pieniężnej, [w:] W. Przybylska-Kapuścińska (red.), Wspótczesna polityka pieniężna, Difin, Warszawa 2008, s. 169.

${ }^{6}$ F.S. Mishkin, The channel of monetary transmission: lessons for monetary policy, National Bureau of Economic Research, Working Paper 1996, no. 8617, s. 2.

${ }^{7}$ W. Przybylska-Kapuścińska, Mechanizm i kanaty transmisji..., s. 182.

${ }^{8}$ F.S. Mishkin, The channel of monetary transmission..., s. 3.
} 
W sytuacji, gdy nominalne stopy procentowe kształtują się na bardzo niskim poziomie, poluzowanie polityki pieniężnej (poprzez zwiększenie podaży pieniądza) może doprowadzić do wzrostu oczekiwanego poziomu cen. Powoduje to spadek realnych stóp procentowych, co następnie stymuluje wzrost dochodów i wydatków w gospodarce. Zdaniem W. Przybylskiej-Kapuścińskiej mechanizm ten pozwala bankowi centralnemu prowadzić skuteczną politykę monetarną nawet $\mathrm{w}$ okresie kryzysu, gdy oficjalne stopy procentowe zostały wcześniej sprowadzone do poziomu bliskiego lub równego zeru?

\section{Metoda badawcza i założenia modelu}

W literaturze przedmiotu podkreśla się, że kwantyfikacja wpływu polityki pieniężnej na gospodarkę jest niezwykle trudna, ponieważ polityka banku centralnego oddziałuje na wiele zmiennych makroekonomicznych, i to w różny sposób $^{10}$. Najczęściej w tego typu badaniach wykorzystywane są wielowymiarowe modele autoregresji wektorowej (tzw. modele VAR; vector autoregression), nazywane modelami o postaci zredukowanej, ponieważ próbują bezpośrednio powiązać zmiany $\mathrm{w}$ instrumentach polityki pieniężnej ze zmianami w finalnych kategoriach makroekonomicznych (PKB, inflacja). Przykłady takich empirycznych analiz nad mechanizmem transmisji można znaleźć m.in. w pracy M. Ehrmanna ${ }^{11}$ oraz A. Webera, R. Gerkego i A. Wormsa ${ }^{12}$.

Pojedynczy model VAR dla $k$-zmiennych endogenicznych składa się z $k$ równań o identycznej strukturze. $\mathrm{W}$ każdym równaniu $\mathrm{w}$ roli zmiennych objaśniających występuje p-opóźnień wszystkich zmiennych uwzględnionych w systemie. Podstawową postać modelu VAR można zapisać następująco $^{13}$ :

${ }^{9}$ W. Przybylska-Kapuścińska, Mechanizm i kanaty transmisji..., s. 183.

${ }^{10}$ R. Kokoszczyński, Współczesna polityka pieniężna w Polsce, PW E, Warszawa 2004, s. 180.

${ }^{11}$ M. Ehrmann, Will EMU Generate Asymmetry? Comparing Monetary Policy Transmission Across European Countries, EUI Working Paper ECO 1998,, no. 28, s. 1-34.

${ }^{12}$ A. Weber, R. Gerke, A. Worms, Changes in euro area monetary transmission?, „Applied Financial Economics" 2011.

${ }^{13}$ G. S. Maddala, Ekonometria, Wyd. Nauk. PWN, Warszawa 2008, s. 609. 


$$
x_{\tau}=A_{0} D_{\tau}+A_{1} x_{\tau-1}+A_{2} x_{\tau-2}+\cdots+A_{p} x_{\tau-p}+\epsilon_{\tau}
$$

gdzie:

$x_{t}=\left[x_{1 t} x_{t 2} \ldots x_{t k}\right]^{T}-$ wektor obserwacji na bieżących wartościach wszystkich zmiennych (wektor zmiennych endogenicznych),

$D_{t}$ - wektor zmiennych deterministycznych (wyraz wolny, zmienna czasowa, zmienne zero-jedynkowe, zmienne sezonowe),

$A_{0}$ - macierz parametrów $(k \times k)$ stojących przy zmiennych deterministycznych,

$A_{i} i=1, \ldots, p$ - macierz parametrów $(k \times k)$ stojących przy $i$-tych opóźnieniach zmiennych endogenicznych,

$\epsilon_{t}-k$-wymiarowy wektor składników losowych $(k \times 1)$.

Modele VAR są powszechnie stosowane w analizie zjawisk ekonomicznych, również o przyczynowo-skutkowym charakterze. Stosując metodologię zaproponowaną przez Peersmana i Smetsa zbudowano model VAR dla strefy euro obrazujący mechanizm transmisji impulsów polityki pieniężnej. W modelu uwzględniono trzy zmienne endogeniczne ${ }^{14}$ : 100),

$y_{t}-$ poziom produkcji (poziom realnego $\mathrm{PKB}$, w cenach stałych $2005=$

$p_{t}-$ poziom cen (zharmonizowany indeks cen konsumpcyjnych HICP, 2005 $=100$ ),

$t_{t}-$ krótkoterminowa stopa procentowa.

W celu porównania związku pomiędzy zmianami stóp procentowych $\mathrm{EBC}$ a aktywnością ekonomiczną $\mathrm{w}$ strefie euro $\mathrm{w}$ okresie przed globalnym kryzysem finansowym i z uwzględnieniem czasu kryzysu, wykorzystano dwa modele VAR:

1) w pierwszym modelu (model I), rozpatrywano okres od 1 kwartału 1998 r. do 3 kwartału 2007r. (39 obserwacji);

2) w drugim modelu (model II), analizowana próba obejmowała okres od 1 kwartału 1998r. do 3 kwartału 2012 r. (59 obserwacji).

W charakterze zmiennej określającej poziom oficjalnej stopy procentowej EBC, została uwzględniona trzymiesięczna stopa procentowa EURIBOR. Stawka ta jest powszechnie uważana za stopę referencyjną rynku pieniężnego w strefie euro ${ }^{15}$. $Z$ danych zawartych na rysunku 2 wynika, że istnieje bardzo silna, dodatnia zależność pomiędzy wysokością stopy oprocentowania podstawowych operacji refinansujących EBC, a wysokością rynkowej stopy procentowej.

${ }^{14}$ G. Peersman, F. Smets, The monetary transmission mechanism in the euro area: evidence from VAR analysis, chapt. 2, [w:] I. Angeloni, A. Kashyap, B. Mojon (eds.), Monetary Transmission in the Euro Area, Cambridge University Press, Cambridge 2003, s. 37.

${ }^{15}$ M. Bohl, P. Siklos, D. Sondermann, European Stock Markets and the ECB's Monetary Policy Surprises, „International Finance” 2008, no. 11(2), s. 122. 
Impuls polityki pieniężne może być zatem utożsamiony ze zmianami krótkoterminowej rynkowej stopy procentowej EURIBOR.

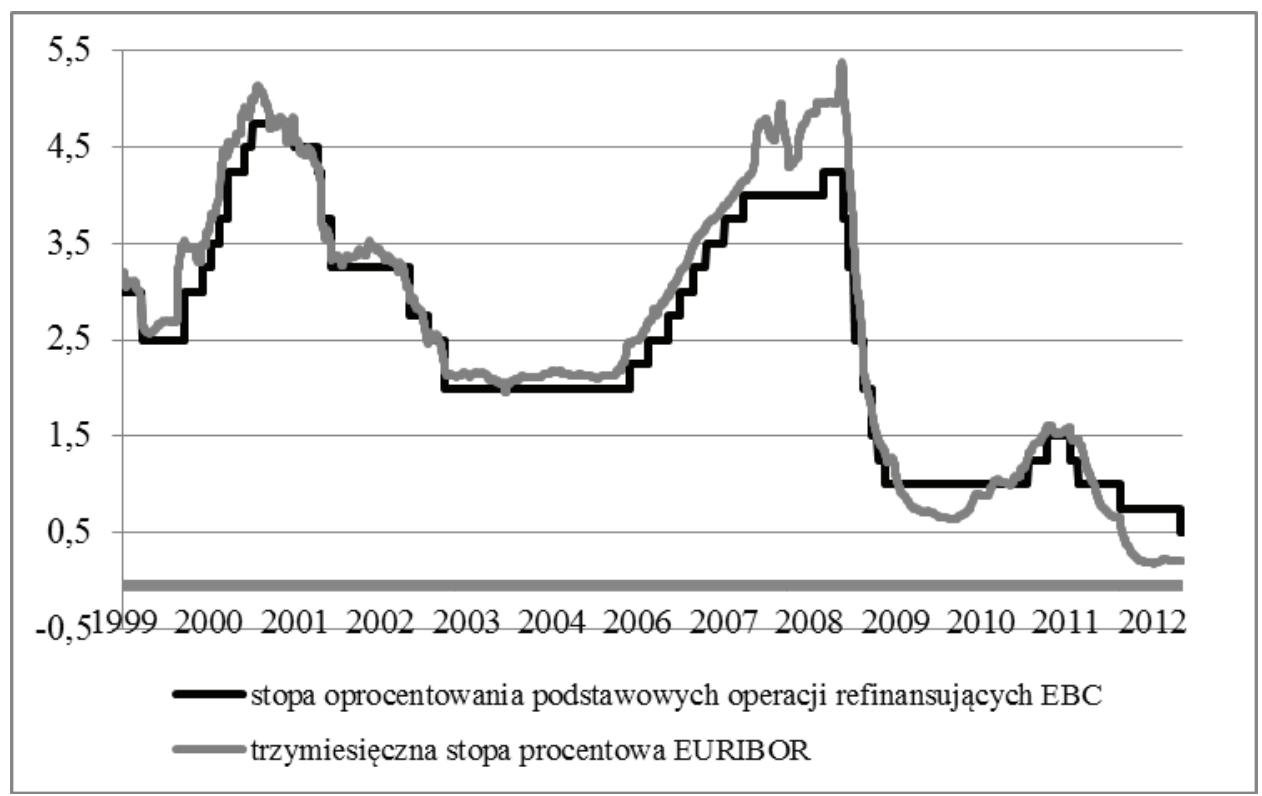

Rysunek 2. Poziom głównej stopy procentowej EBC i trzymiesięcznej stopy EURIBOR w latach 1999-2012 (w \%)

Źródło: opracowanie własne na podstawie bazy danych Reuters (dostęp 10.05.2013).

Tabela 1. Wyniki testu ADF dla poszczególnych szeregów czasowych

\begin{tabular}{|l|c|c|c|c|}
\hline \multirow{2}{*}{ Zmienna } & \multicolumn{2}{|c|}{ Poziomy zmiennych } & \multicolumn{2}{c|}{ Sezonowe przyrosty zmiennych } \\
\cline { 2 - 5 } & $\begin{array}{c}\text { statystyka testu: } \\
\text { tau_c(1) }\end{array}$ & $\begin{array}{c}\text { asymptotyczna } \\
\text { wartość } \mathrm{p}\end{array}$ & $\begin{array}{c}\text { statystyka testu: } \\
\text { tau_c(1) }\end{array}$ & $\begin{array}{c}\text { asymptotyczna } \\
\text { wartość p }\end{array}$ \\
\hline $\bar{i}_{t}$ & $-2,15312$ & 0,2239 & $-4,83875$ & $4,313 \mathrm{e}-005$ \\
\hline$p_{t}$ & 0,714087 & 0,9925 & $-3,37256$ & 0,01196 \\
\hline$y_{t}$ & $-2,05381$ & 0,2639 & $-2,99273$ & 0,03559 \\
\hline
\end{tabular}

Źródło: opracowanie własne z wykorzystaniem programu Gretl (dotyczy tabel 1-5).

Przed dokonaniem estymacji modelu VAR, szeregi czasowe uwzględnione w badaniu poddano testowaniu na obecność pierwiastków jednostkowych. W załączniku 1 (rysunek 6) przedstawiono kształtowanie się poszczególnych zmiennych wchodzących w skład wektora zmiennych endogenicznych, zarówno poziomów, jak i przyrostów. $Z$ kolei w tabeli 1 pokazano wyniki rozszerzonego 
testu Dickeya-Fullera - $\mathrm{ADF}^{16}$ (Augmented Dickey-Fuller TEST), zastosowanego w celu oszacowania stacjonarności rozpatrywanych zmiennych.

W przypadku wszystkich poziomów zmiennych (tabela 1), empiryczny poziom istotności statystyki ADF był większy od poziomu istotności rzędu 0,05, co wskazywało na niestacjonarność tych szeregów czasowych. Brak stacjonarności zmiennych wymusił modyfikację postaci funkcyjnej modelu VAR, która polegała na wykorzystaniu sezonowych przyrostów poszczególnych zmiennych. Analizując informacje zaprezentowane w tabeli 1 można zauważyć, że sezonowe przyrosty zmiennych są stacjonarne, co oznacza, że analizowane zmienne są zintegrowane stopnia pierwszego (niestacjonarne).

Z uwagi na fakt, że w badaniu zostały uwzględnione dane kwartalne, sezonowe przyrosty zmiennych wyliczono według następującej formuły:

gdzie:

$$
\left(\begin{array}{c}
\Delta x \\
x
\end{array}\right)_{t}=\frac{x_{t}-x_{t-4}}{x_{t-4}} \times 100 \%
$$

$x_{z}-$ wartość zmiennej X w okresie $t$,

$x_{z-4}-$ wartość zmiennej X w okresie i -4 .

Szacunki zostały wykonane w pakiecie ekonometrycznym Gretl. Dane statystyczne pochodziły z serwisu Thomson Reuters oraz tablic statystycznych opracowanych przez Europejski Urząd Statystyczny (Eurostat).

Tabela 2.Wartości kryteriów informacyjnych dla modelu I i modelu II

\begin{tabular}{|c|c|c|c|c|c|}
\hline Opóźnienia & Loglik & $\begin{array}{c}\text { Poziom } \\
\text { istotności } \\
\text { P(lr) }\end{array}$ & AIC & BIC & HQC \\
\hline \multicolumn{7}{|c|}{$1998: 1-2007: 3$} \\
\hline 1 & $-194,34576$ & & 10,860303 & 11,377436 & 11,044295 \\
\hline 2 & $-170,88187$ & 0,00000 & 10,099046 & $* 11,004027$ & $* 10,421031$ \\
\hline 3 & $-159,68921$ & 0,00773 & 9,983643 & 11,276474 & 10,443622 \\
\hline 4 & $-154,41457$ & 0,30787 & 10,179714 & 11,860395 & 10,777687 \\
\hline 5 & $-136,99030$ & 0,00006 & $* 9,736331$ & 11,804861 & 10,472298 \\
\hline \multicolumn{7}{|c|}{$1998: 1-2012: 3$} \\
\hline 1 & $-339,87776$ & 12,237164 & 12,770037 & 12,444729 \\
\hline 2 & $-296,99454$ & 0,00000 & $11,068777 *$ & $* 11,921374$ & $* 11,400881$ \\
\hline 3 & $-291,03517$ & 0,21793 & 11,173627 & 12,345948 & 11,630269 \\
\hline 4 & $-280,79312$ & 0,01515 & 11,130797 & 12,622842 & 11,711979 \\
\hline 5 & $-273,23112$ & 0,08759 & 11,180384 & 12,992152 & 11,886104 \\
\hline
\end{tabular}

Gwiazdka (*) wskazuje najlepszą (to jest minimalną) wartość dla odpowiednich kryteriów informacyjnych.

${ }^{16}$ Test Dickeya-Fullera ADF (nazywany również testem pierwiastka jednostkowego, (unit root tests) - zakłada w hipotezie zerowej niestacjonarność szeregu czasowego. 
Długość opóźnienia modelu VAR (tj. rząd opóźnienia $p$ ) została ustalona jako wypadkowa kryteriów informacyjnych, do których zalicza się ${ }^{17}$ :

1) kryterium informacyjne Akaike'a (AIC),

2) kryterium informacyjne Schwartza (BIC),

3) kryterium informacyjne Hannana-Quinna (HQ).

Opierając się na danych zamieszczonych $\mathrm{w}$ tabeli 2 , w badaniu przyjęto dwuokresowe opóźnienie między zmiennymi objaśniającymi a zmienną objaśnianą (tj. dwa kwartały).

Wykorzystany w badaniu model VAR przyjął ostatecznie następującą postać:

$$
x_{z}=A_{0} D_{t}+A_{1} x_{t-1}+A_{2} x_{t-2}+\epsilon_{z}
$$

gdzie:

$x_{t}=\left[\Delta i_{\tau} \Delta p_{t} \Delta y_{t}\right]^{3}$-wektor zmiennych endogenicznych,

$\Delta i_{t}$ - sezonowe przyrosty trzymiesięcznej nominalnej stopy procentowej EURIBOR,

$\Delta p_{t}-$ roczne tempo wzrostu indeksu cen HICP $(2005=100)$,

$\Delta y_{t}-$ roczne tempo wzrostu realnego PKB w cenach stałych $(2005=100)$,

$D_{t}-$ wektor zmiennych deterministycznych (wyraz wolny),

$A_{0}$ - macierz parametrów stojących przy zmiennych deterministycznych,

$A_{i} i=1,2$ - macierz parametrów stojących przy i-tych opóźnieniach zmiennych,

$\epsilon_{t}-3$-wymiarowy wektor składników losowych.

W modelu II (1998:1-2012:3), poza wymienionymi powyżej zmiennymi endogenicznymi, uwzględniono dodatkowo zmienną egzogeniczną, tj.:

u2007_2010 - zmienna zero-jedynkowa uwzględniająca okres globalnego kryzysu finansowego (przyjmuje wartości $1 \mathrm{w}$ okresie od 4 kwartału 2007 r. do 2 kwartału 2010 r.).

Kolejność zmiennych endogenicznych wchodzących w skład wektora $x_{t}$ wynikała $z$ dekompozycji Cholesky'ego ${ }^{18}$. Na podstawie narzuconej kolejności uszeregowania zmiennych w systemie, można stwierdzić, że ${ }^{19}$ :

1) zmienna $\Delta i_{t}-$ jest ,najbardziej egzogeniczną” zmienną modelu - jej zaburzenie wpływa na wszystkie pozostałe zmienne,

2) zmienna $\Delta p_{t}$ - jest zmienną oddziałującą na $\Delta y_{t}$ (ale nie na poprzednią),

${ }^{17}$ T. Kufel, Ekonometria. Rozwiazywanie problemów z wykorzystaniem programu GRETL, Wyd. Nauk. PWN, Warszawa 2007, s. 157.

${ }^{18}$ Dekompozycja Cholesky'ego - to porządkowanie „ważności” zmiennych; nakłada pewne założenia na strukturę powiązań zmiennych.

${ }^{19}$ E. Kusideł, Modele wektorowo-autoagresyjne VAR: metodologia i zastosowania, Wydawnictwo Absolwent, Łódź 2000, s. 40. 
3) zmienna $\Delta y_{t}$ - jest endogeniczną zmienną modelu - na tą zmienną wpływają jednocześnie wszystkie zaburzenia w pozostałych równaniach.

W celu sprawdzenia odporności wyników na tak zaproponowaną dekompozycję, zmieniano kolejność zmiennych objaśniających wprowadzanych do modelu VAR. Otrzymane rezultaty badania wskazały, że funkcje reakcji nie uległy poważniejszym zmianom.

\section{Wyniki analizy empirycznej}

Model VAR jest przydatny do praktycznego wykorzystania, gdy rozwinięcie procesów endogenicznych względem składników losowych jest zbieżne oraz tworzy stacjonarne procesy. T. Kufel podkreśla, że warunek, aby wszystkie pierwiastki równania charakterystycznego były mniejsze co do modułu od jedności jest podstawowym założeniem praktycznego zastosowania modelu $\mathrm{VAR}^{20}$.

Dane zawarte na rysunku 3 wskazują, że w wszystkie pierwiastki w oszacowanych trzyrównaniowych modelach VAR, są mniejsze, co do modułu, od jedności. Można zatem sądzić, że prezentowane modele VAR są stabilne ${ }^{21}$ i mogą być wykorzystane do wyznaczenia funkcji odpowiedzi na impuls oraz dekompozycji wariancji błędu prognozy zmiennych.
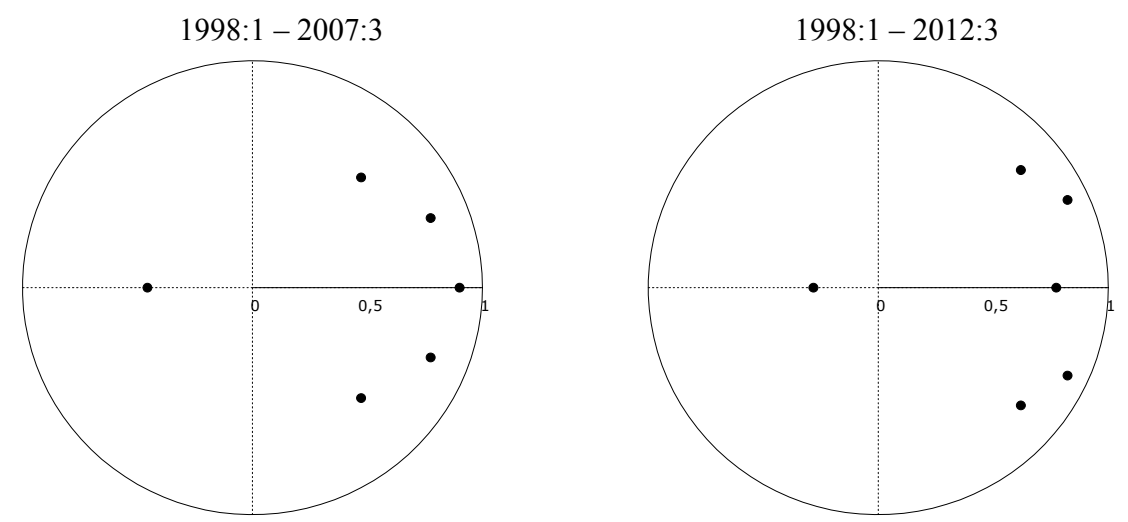

Rysunek 3. Pierwiastki równania charakterystycznego VAR w modelu I i modelu II

Źródło: opracowanie własne z wykorzystaniem programu Gretl (dotyczy rysunków 3-6).

W tym miejscu warto również zwrócić uwagę, że test autokorelacji Q, pozwala stwierdzić brak autokorelacji reszt $\mathrm{w}$ rozpatrywanych model VAR. Empiryczne poziomy istności dla poszczególnych równań w modelu I i II są

${ }^{20}$ T. Kufel, Ekonometria. Rozwiąywanie..., s. 169-170.

${ }^{21}$ E. Kusideł, Modele wektorowo-autoagresyjne... 
większe od poziomu istotności rzędu 0,05 . Sytuacja ta oznacza, że nie ma podstaw do odrzucenia hipotezy zerowej o zerowej autokorelacji składników losowych poszczególnych równań VAR, co jest dodatkowym potwierdzeniem właściwości wykorzystanej procedury doboru i transformacji zmiennych ${ }^{22}$.

Tabela 3.Test autokorelacji Q* (Ljunga-Boxa)

\begin{tabular}{|l|c|l|}
\hline & $\begin{array}{c}\text { Wartość statystyki } \\
\text { Ljunga-Boxa }\end{array}$ & \multicolumn{1}{|c|}{ Wartość $\mathrm{p}$} \\
\hline \multicolumn{3}{|c|}{$1998: 1-2007: 3$} \\
\hline Równanie 1: $\Delta i_{t}$ & 0,224894 & $\mathrm{p}=\mathrm{P}($ Chi-kwadrat $(2)>0,224894)=0,894$ \\
\hline Równanie 2: $\Delta p_{t}$ & 0,708213 & $\mathrm{p}=\mathrm{P}($ Chi-kwadrat $(2)>0,708213)=0,702$ \\
\hline Równanie 3: $\Delta y_{t}$ & 2,01184 & $\mathrm{p}=\mathrm{P}($ Chi-kwadrat $(2)>2,01184)=0,366$ \\
\hline \multicolumn{3}{|c|}{$1998: 1-2012: 3$} \\
\hline Równanie 1: $\Delta i_{t}$ & 2,69971 & $\mathrm{p}=\mathrm{P}($ Chi-kwadrat $(2)>2,69971)=0,259$ \\
\hline Równanie 2: $\Delta p_{t}$ & 0,0414406 & $\mathrm{p}=\mathrm{P}($ Chi-kwadrat $(2)>0,0414406)=0,979$ \\
\hline Równanie 3: $\Delta y_{t}$ & 0,421115 & $\mathrm{p}=\mathrm{P}($ Chi-kwadrat $(2)>0,421115)=0,81$ \\
\hline
\end{tabular}

*Test autokorelacji Q przy hipotezach:

$\mathrm{H}_{0}$ : brak autokorelacji

$\mathrm{H}_{1}$ : występuje autokorelacja

\subsection{Testowanie przyczynowości na podstawie modelu VAR dla strefy euro}

Wstępna analiza współzależności pomiędzy szeregami czasowymi, uwzględnionymi w badaniu, została przeprowadzona według testu przyczynowości Grangera (causality analysis). Zgodnie z definicją zaproponowaną przez Charemzę i Deadmana „zmienna $x$ jest przyczyną $y$ w sensie Grangera (co oznaczamy $x \rightarrow y$ ), jeżeli bieżące wartości $y$ można prognozować $\mathrm{z}$ większą dokładnością przy użyciu przeszłych wartości $x$ niż bez ich wykorzystania, przy nie zmienionej pozostałej informacji ${ }^{23}$.

W praktyce, badanie przyczynowości w sensie Grangera w modelu VAR sprowadza się do testowania restrykcji zerowych dla parametrów stojących przy zmiennych opóźnionych ${ }^{24}$. W pakiecie ekonometrycznym Gretl analiza przyczynowości modelu VAR odbywa się za pomocą testu F, przy hipotezach"25:

$\mathrm{H}_{0}$ : brak przyczynowości w sensie Grangera

$\mathrm{H}_{1}$ : występuje przyczynowość w sensie Grangera

\footnotetext{
${ }^{22}$ Ibidem, s. 20.

${ }^{23}$ W. Charemza, D. Deadman, Nowa ekonometria, P W E, Warszawa 1997, s. 158.

${ }^{24}$ Ibidem, s. 157.

${ }^{25}$ T. Kufel, Ekonometria. Rozwiazywanie..., s. 169.
} 
Tabela 4. Wyniki testu przyczynowości Grangera dla modelu I (1998-2007)

\begin{tabular}{|c|c|c|c|c|}
\hline & \multicolumn{3}{|c|}{ Zmienne traktowane jako przyczyny } \\
\hline & & $\Delta i_{t}$ & $\Delta p_{t}$ & $\Delta y_{t}$ \\
\hline \multirow{3}{*}{$\begin{array}{l}\text { Zmienne } \\
\text { traktowane jako } \\
\text { oddziaływane }\end{array}$} & $\Delta i_{\mathrm{t}}$ & $\begin{array}{c}\mathrm{F}(2,32)=66,558 \\
{[0,0000]}\end{array}$ & $\begin{array}{c}\mathrm{F}(2,32)=1,388 \\
{[0,2642]}\end{array}$ & $\begin{array}{c}\mathrm{F}(2,32)=1,1264 \\
{[0,3367]}\end{array}$ \\
\hline & $\Delta p_{t}$ & $\begin{array}{c}\mathrm{F}(2,32)=0,24249 \\
{[0,7861]}\end{array}$ & $\begin{array}{c}F(2,32)=37,206 \\
{[0,0000]}\end{array}$ & $\begin{array}{c}\mathrm{F}(2,32)=3,2773 \\
{[0,0507]}\end{array}$ \\
\hline & $\Delta y_{t}$ & $\begin{array}{c}\mathrm{F}(2,32)=2,4847 \\
{[0,0993]}\end{array}$ & $\begin{array}{c}\mathrm{F}(2,32)=3,4265 \\
{[0,0448]}\end{array}$ & $\begin{array}{c}\mathrm{F}(2,32)=14,964 \\
{[0,0000]}\end{array}$ \\
\hline
\end{tabular}

Tabela 5. Wyniki testu przyczynowość Grangera dla modelu II (1998-2012)

\begin{tabular}{|c|c|c|c|c|}
\hline & \multicolumn{3}{|c|}{ Zmienne traktowane jako przyczyny } \\
\hline & & $\Delta i_{i}$ & $\Delta p_{t}$ & $\Delta y_{t}$ \\
\hline \multirow{3}{*}{$\begin{array}{l}\text { Zmienne } \\
\text { traktowane jako } \\
\text { oddziaływane }\end{array}$} & $\Delta i_{t}$ & $\begin{array}{c}\mathrm{F}(2,51)=133,53 \\
{[0,0000]}\end{array}$ & $\begin{array}{c}\mathrm{F}(2,51)=1,0936 \\
{[0,3427]}\end{array}$ & $\begin{array}{c}\mathrm{F}(2,51)=1,5101 \\
{[0,2306]}\end{array}$ \\
\hline & $\Delta p_{t}$ & $\begin{array}{c}\mathrm{F}(2,51)=0,69302 \\
{[0,5047]}\end{array}$ & $\begin{array}{c}\mathrm{F}(2,51)=53,521 \\
{[0,0000]}\end{array}$ & $\begin{array}{c}\mathrm{F}(2,51)=6,5151 \\
{[0,0030]}\end{array}$ \\
\hline & $\Delta y_{t}$ & $\begin{array}{c}\mathrm{F}(2,51)=0,56366 \\
{[0,5726]}\end{array}$ & $\begin{array}{c}\mathrm{F}(2,51)=13,191 \\
{[0,0000]}\end{array}$ & $\begin{array}{c}\mathrm{F}(2,51)=69,53 \\
{[0,0000]}\end{array}$ \\
\hline
\end{tabular}

Uzyskane wyniki testu przyczynowości w sensie Grangera (tabela 4 i 5) wskazują, że w latach 1998-2007 oraz 1998-2012 zmiany stopy procentowej kształtowały się niezależnie od zmian rocznej stopy inflacji i rocznej stopy wzrostu gospodarczego. Ponadto, przyrosty stopy procentowej nie były przyczyną zmian stopy inflacji. Jednokierunkowy przebieg zależności pomiędzy stopą procentową, a realną sferą gospodarki strefy euro występował jedynie w latach 1998-2007. Zmiana rynkowej krótkookresowej stopy procentowej wpływała na tempo wzrostu realnego PKB na poziomie istotności 0,1. Analizując informacje zamieszczone $\mathrm{w}$ powyższych tabelach można także zauważyć wzajemną zależność przyczynowo-skutkową pomiędzy dynamiką realnego PKB oraz dynamiką ogólnego poziomu cen w Eurosystemie.

\subsection{Funkcje odpowiedzi na impuls monetarny EBC}

Uzyskane wyniki analizy przyczynowości w sensie Grangera są w pewnym stopniu zgodne z zamieszczonymi we wstępie rozważeniami teoretycznymi. Nie opisują one jednak siły i szybkości reakcji pomiędzy zmiennymi włączonymi do modelu VAR. Problem ten pozwala rozwiązać funkcja odpowiedzi na impuls (impulse response function - IRF). Za jej pomocą można sprawdzić, jakie skutki dla systemu spowoduje zmiana jednej ze zmiennych występujących w modelu ${ }^{26}$.

${ }^{26}$ J. Rembeza, G. Przekota, Wplyw stóp procentowych na wartość indeksu giełdowego WIG, „Bank i Kredyt” 2008, nr 8, s. 65. 
Dane zawarte na rysunku 4 przedstawiają reakcję zmiennych makroekonomicznych na nieoczekiwany (szokowy) wzrost trzymiesięcznej stopy procentowej (o jedno odchylenie standardowe) w kolejnych 30 kwartałach. Rozpatrując poszczególne funkcje odpowiedzi na impuls monetarny można zauważyć, silną, opóźnioną w czasie reakcję zmiennych włączonych do modelu VAR na zaburzenie przyrostów krótkookresowej stopy procentowej.

Funkcja IRF reakcji rocznej stopy wzrostu gospodarczego pokazuje, że wzrost stopy procentowej wywołuje $\mathrm{w}$ długim okresie spadek dynamiki realnego PKB, co jest zgodne $\mathrm{z}$ teorią ekonomii. Impuls stopy procentowej wywiera maksymalny wpływ na zmianę dynamiki produkcji po około 12 kwartałach (w latach 1998-2007) i po około 10 kwartałach (w latach 1998-2012). Pogłębiona analiza krótkookresowa wskazuje również na, sprzeczny z teorią ekonomii, początkowy wzrost dynamiki realnego PKB wywołany jednorazowym wzrostem stopy procentowej. Taka reakcja produkcji na zmianę polityki stóp procentowych określana jest $\mathrm{w}$ literaturze przedmiotu terminem output puzzle. Przypuszcza się, że odpowiedzią na tą zagadkę jest silniejszy wpływ na dynamikę produkcji szoków podażowych niż popytowych ${ }^{27}$.

$\mathrm{Z}$ analizy IRF reakcji rocznej stopy inflacji na impuls stopy procentowej wynika, że wzrost oficjalnej stopy procentowej wywierał maksymalny wpływ na zmianę dynamiki ogólnego poziomu cen po około 12 kwartałach zarówno w okresie 1998-2007, jak i w latach 1998-2012. Reakcja stopy inflacji na impuls monetarny zawierała w sobie także charakterystyczny element tzw. price puzzle, czyli przejściowy wzrost stopy inflacji w pierwszym okresie po podwyżce stopy procentowej ${ }^{28}$.

Opierając się na informacjach zawartych na rysunku 4 można również odnotować, że w latach 1998-2007 reakcje wszystkich zmiennych makroekonomicznych na impuls polityki pieniężnej wygasały bardzo powoli (po około 16 kwartałach). Z kolei w wyniku wydłużenia się okresu próby badawczej o kolejne 20 kwartałów (tj. model II) zmienił się kształt funkcji odpowiedzi na impuls. W latach 1998-2012 funkcje IRF miały mniej łagodny przebieg, a zaburzenie modelu VAR przez szok monetarny nie powodowało przywrócenia systemu do stanu równowagi nawet w stosunkowo długim horyzoncie czasowym. Impuls monetarny był dłużej podtrzymywany przez równanie stopy wzrostu gospodarczego i stopy inflacji niż w okresie 1998-2007.

${ }^{27}$ R.G. Lachota, Ekonometryczna analiza determinantów inflacji i stopy procentowej, Wyd. Biblioteka, Łódź, 2005, s. 147.

${ }^{28}$ R. Kokoszczyński, Wspótczesna polityka pieniężna ..., s. 272. 
Odpowiedź $\Delta y_{t}$ na impuls z $\Delta i_{t}$
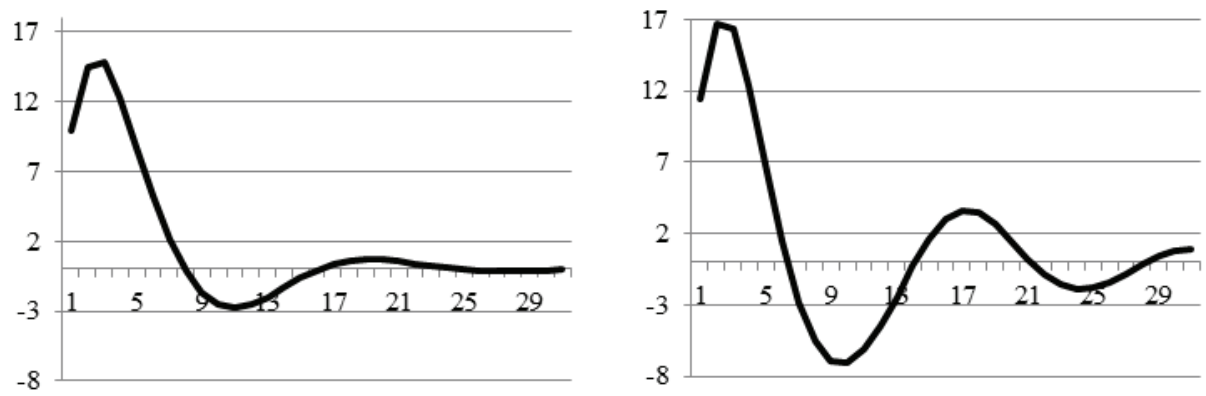

Odpowiedź $\Delta p_{t}$ na impuls z $\Delta i_{t}$
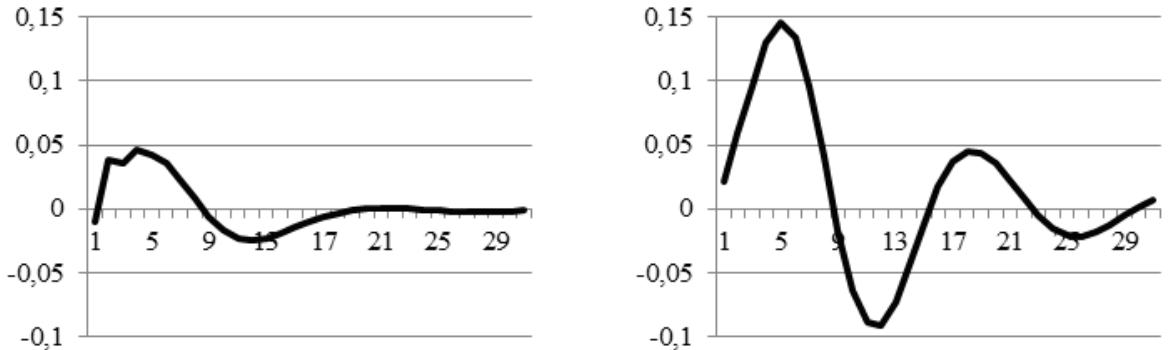

Odpowiedź $\Delta i_{t}$ na impuls z $\Delta i_{t}$
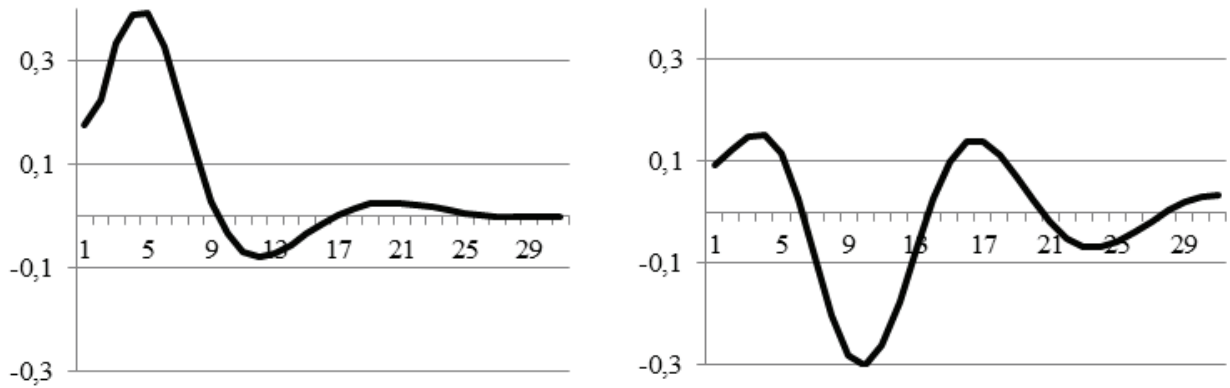

Rysunek 4. Funkcja reakcji poszczególnych zmiennych makroekonomicznych na impuls stopy procentowej w modelu I i modelu II

\subsection{Dekompozycja wariancji błędu prognozy zmiennych uwzględnionych w modelu VAR dla strefy euro}

W niniejszym pracy zastosowano również metodę pomocniczą $\mathrm{w}$ badaniu interakcji pomiędzy zmiennymi włączonymi do modelu VAR, tj. przeprowadzono dekompozycję wariancji ich błędów prognozy (ariance decomposition). E. Kusideł podkreśla, że dekompozycja wariancji wyjaśnia, jaki udział w objaśnianiu błędu 
prognozy danej zmiennej mają inne zmienne uwzględnione $\mathrm{w}$ badaniu ${ }^{29}$. Ujęcie graficzne dekompozycji wariancji dla poszczególnych zmiennych wchodzących w skład modelu I i II zamieszczono poniżej.

Dekompozycja wariancji dla zmiennej $\Delta i_{t}$
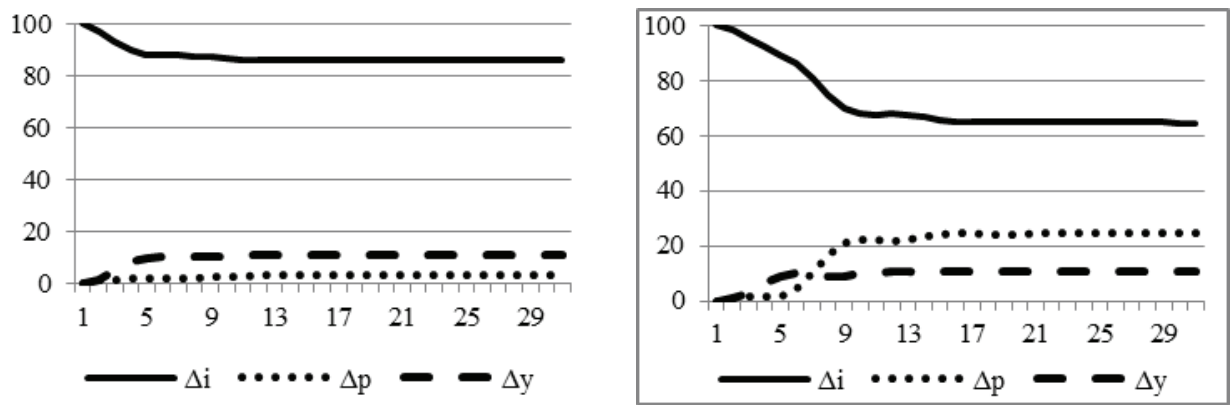

Dekompozycja wariancji dla zmiennej $\Delta p_{\text {t }}$
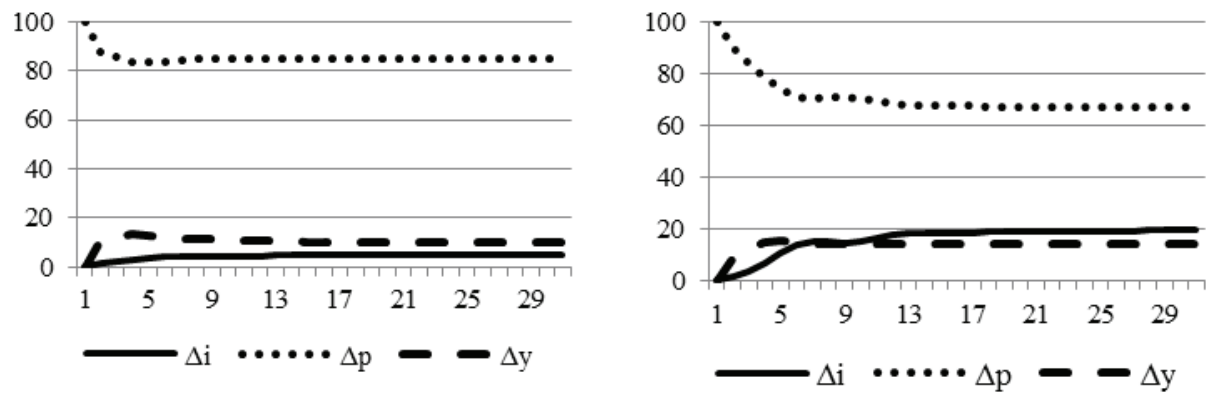

Dekompozycja wariancji dla zmiennej $\Delta y_{t}$
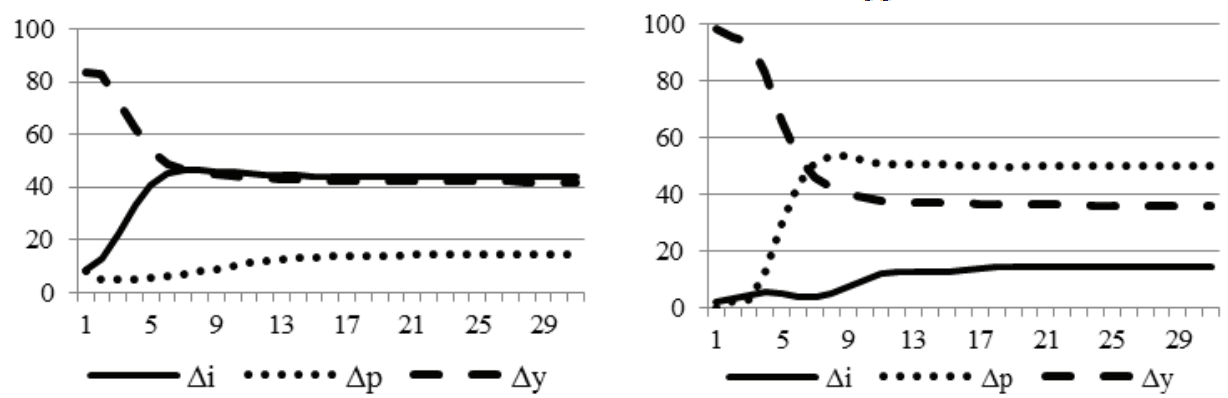

Rysunek 5. Dekompozycja wariancji w modelu I i modelu II

Z danych zawartych na rysunku 5 wynika, że w latach 1998-2007, w krótkim okresie czasu, w błędzie prognozy przyrostów stopy procentowej

${ }^{29}$ E. Kusideł, Modele wektorowo-autoagresyjne..., s. 42. 
$\left(\Delta i_{t}\right)$ blisko 100-procentowy udział miały zmiany tej właśnie zmiennej. Po 30 kwartałach zmienna $\Delta i_{t}$ w około $11 \%$ zależała od wartości rocznego tempa wzrostu realnego PKB $\left(\Delta y_{t}\right)$, a tylko w około 3\% od wartości rocznej stopy inflacji $(\Delta p)$. Podobną strukturą dekompozycji wariancji charakteryzowało się również roczne tempo wzrostu ogólnego poziomu cen. Roczna stopa wzrostu gospodarczego $\left(\Delta y_{t}\right)$ natomiast $\mathrm{w}$ dużym stopniu zależała od wartości zmiennej $\Delta i_{\text {z }}$ (w około $44 \%$ ) oraz zmiennej $\Delta p_{t}$ (w około $42 \%$ ).

W modelu II, w którym uwzględniono dłuższy okres badanej próby, dekompozycja wariancji błędu prognozy przyrostów stopy procentowej była w około $65 \%$ zależna od własnych wartości, w około $25 \%$ od wartości zmiennej $\Delta \mathrm{p}_{\mathrm{t}}$, a w około $10 \%$ od wartości zmiennej $\Delta y_{\mathrm{t}}$. Z kolei wariancja stopy wzrostu gospodarczego tylko w około $36 \%$ wyjaśniana była przez własne wartości, aż w około 50\% przez wartości stopy inflacji, a w około $14 \%$ przez zmianę stopy procentowej.

Z powyższej analizy można wysnuć wniosek, że dekompozycja wariancji błędu prognozy poszczególnych zmiennych włączonych do modelu VAR uległa zmianie wraz z wydłużeniem okresu badania. Po pierwsze, w latach 1998-2007 tempo wzrostu realnego PKB w większym stopniu reagowało na zmiany stopy procentowej niż w latach 1998-2012. Po drugie, w latach 1998-2012 roczna stopa inflacji w większym stopniu była zależna od zmiany krótkoterminowej stopy procentowej niż w okresie poprzednim. Przypuszczać można zatem, że w czasie globalnego kryzysu finansowego mechanizm transmisji impulsów polityki pieniężnej EBC nie wywierał wpływu na realną sferę gospodarki. Ponadto, w czasie kryzysu jednolita polityka pieniężna $\mathrm{w}$ większym stopniu przyczyniała się do kształtowania oczekiwań inflacyjnych w strefie euro niż w ciągu pierwszych kilku lat funkcjonowania Eurosystemu.

\section{Zakończenie}

Reasumując można stwierdzić, że przeprowadzone badanie empiryczne potwierdziło zróżnicowaną reakcję gospodarki strefy euro na impuls monetarny w latach 1998-2007 oraz w latach 1998-2012. W stabilnych warunkach gospodarczych polityka stóp procentowych EBC wpływała na sferę realną gospodarki. Restrykcyjna polityka monetarna powodowała obniżenie dynamiki stopy wzrostu gospodarczego i stopy inflacji, w okresie od 1 roku do 4 lat.

Globalny kryzys finansowy zaburzył sprawne funkcjonowanie mechanizmu transmisji impulsów polityki pieniężnej EBC. W latach 1998-2012 reakcja głównych zmiennych makroekonomicznych na szok stopy procentowej cechowała się większą zmiennością niż w okresie poprzednim. Na tej podstawie można sądzić, że, zwłaszcza poprzez kanał stopy procentowej, została osłabiona zdolność banku centralnego Eurosystemu do oddziaływania na procesy makroekonomicz- 
ne. Opierając się na rezultatach dekompozycji wariancji warto zauważyć, że antykryzysowa polityka pieniężna EBC sprawiła znaczny wzrost znaczenia oczekiwań inflacyjnych w procesie transmisji impulsów monetarnych do sfery realnej gospodarki strefy euro.

\section{Literatura}

Bohl M., Siklos P., Sondermann D., European Stock Markets and the ECB's Monetary Policy Surprises, „International Finance” 2008, no. 11(2),

Charemza W., Deadman D., Nowa ekonometria, PWE, Warszawa 1997.

Ehrmann M., Will EMU Generate Asymmetry? Comparing Monetary Policy Transmission Across European Countries, EUI Working Paper ECO 1998, no. 28.

European Central Bank, The Monetary Policy of the ECB, Frankturt am Mein 2011.

Ireland P. N., The monetary transmission mechanism, Federal Reaseve Bank of Boston, Working Papers 2005, no. 60-1.

Kokoszczyński R., Współczesna polityka pieniężna w Polsce, PWE, Warszawa 2004.

Kufel T., Ekonometria. Rozwiąywanie problemów z wykorzystaniem programu GRETL, Wyd. Nauk. PWN, Warszawa 2007.

Kusideł E., Modele wektorowo-autoagresyjne VAR: metodologia i zastosowania, Absolwent, Łódź 2000.

Lachota R.G., Ekonometryczna analiza determinantów inflacji i stopy procentowej, Wyd. Biblioteka, Łódź 2005.

Maddala G.S., Ekonometria, Wyd. Nauk. PWN, Warszawa 2008.

Mishkin F.S., The channel of monetary transmission: lessons for monetary policy, National Bureau of Economic Research, Working Paper 1996, no. 8617.

Peersman G., Smets F., The monetary transmission mechanism in the euro area: evidence from VAR analysis, chapt. 2, [w:] I. Angeloni, A. Kashyap , B. Mojon (red.), Monetary Transmission in the Euro Area, Cambridge University Press, Cambridge 2003.

Przybylska-Kapuścińska W., Mechanizm i kanały transmisji polityki pieniężnej, [w:] W. PrzybylskaKapuścińska (red.), Współczesna polityka pieniężna, Difin, Warszawa 2008.

Pszczółka I., Mechanizmy transmisyjne zmian podaży pieniądza i nominalnych stóp procentowych, [w:] J.L. Bednarczyk [red.], Teoria i polityka stóp procentowych we wspótczesnej gospodarce, Wyd. Politechniki Radomskiej, Radom 2007.

Rembeza J., Przekota G., Wpływ stóp procentowych na wartość indeksu giełdowego WIG, „Bank i Kredyt" 2008, nr 8.

Rosiek J., Polityka monetarna $w$ dobie kryzysu gospodarczego - wybrane aspekty oddziatywania, [w:] Z. Dach (red.), Polityka makroekonomiczna w warunkach kryzysu i jej wplyw na gospodarke. Teoria i praktyka, Wolters Kluwer, Warszawa 2011.

Weber A., Gerke R., Worms A., Changes in euro area monetary transmission?, „Applied Financial Economics" 2011.

\section{Streszczenie}

W artykule zawarte zostało porównanie wpływu zmian oficjalnej stopy procentowej EBC na inflację i aktywność gospodarczą strefy euro w okresie przed globalnym kryzysem finansowym oraz $\mathrm{z}$ uwzględnieniem okresu kryzysu. Wyniki badania wykazały zróżnicowaną reakcję głównych zmiennych makroekonomicznych na szok stopy pro- 
centowej w latach 1998-2007 oraz w latach 1998-2012.Wythumaczeniem tego zjawiska może być osłabienie znaczenia kanału stopy procentowej w mechanizmie transmisji impulsów polityki pieniężnej ECB w czasie kryzysu i wzrost znaczenia innych czynników w kształtowaniu procesów sfery realnej, np. oczekiwań inflacyjnych.

\section{Summary}

\section{THE EFFECT OF ECB INTEREST RATES CHANGES ON INFLATION AND ECONOMIC ACTIVITY OF THE EURO AREA - VERIFICATION BY USING THE VECTOR AUTOREGRESSION MODEL (VAR)}

This article was provided a comparison the effects of changes in official ECB interest rates on inflation and economic activity of the euro area economy in the period before the global financial crisis and taking into account the period of crisis. Results from the studies showed different response of key macroeconomic variables to interest rate shocks in the years 1998-2007 and in the period 1998-2012. The explanation for this phenomenon may reflect the fact that the importance of the interest rate channel in the transmission mechanism of monetary policy the ECB was weakened during the crisis and increased the importance of other factors in the development of the real economy processes, such as inflation expectations. 


\section{Załącznik}

Poziomy zmiennych

EURIBOR_3M

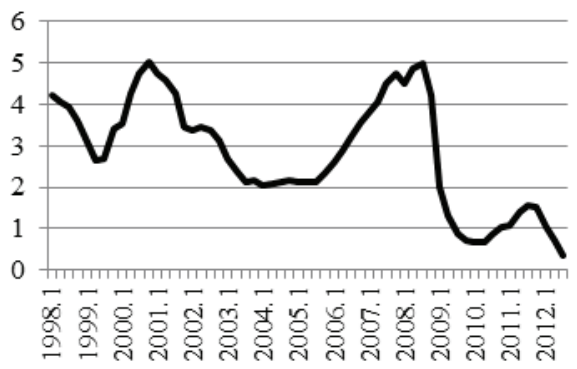

ln_real_GDP

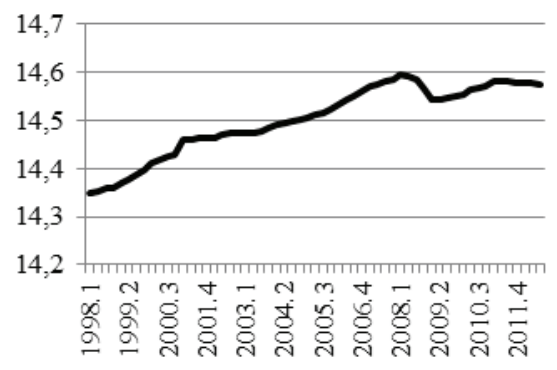

$\ln$ HICP

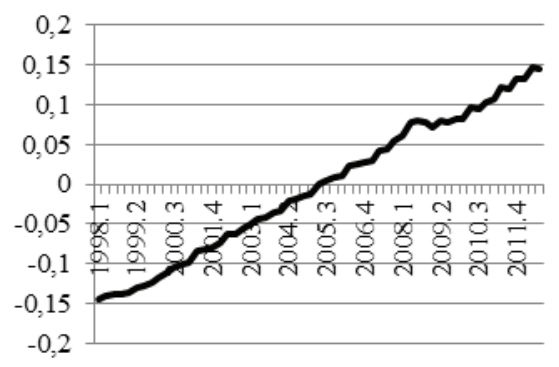

Sezonowe przyrosty zmiennych

st_EURIBOR_3M

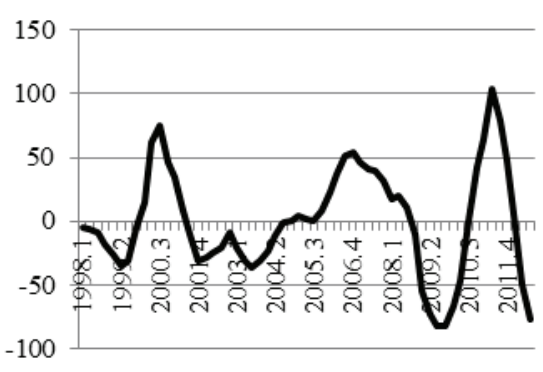

st_real_GDP

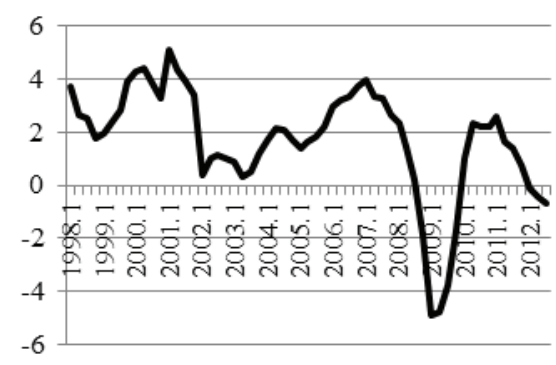

st HICP

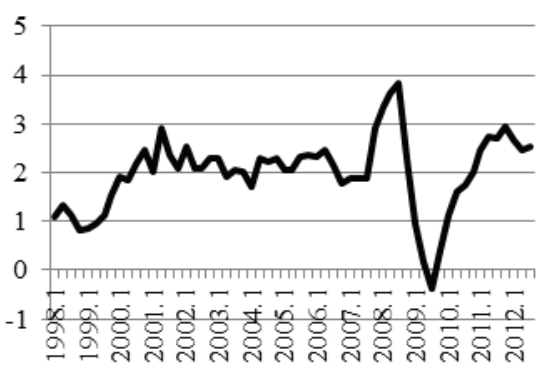

Rysunek 6. Wykresy poszczególnych zmiennych uwzględnionych w modelu VAR 